\title{
PRELIMINARY STUDY OF BOVINE COLOSTRUM QUALITY IN LATVIA
}

\author{
Svetlana Baltrukova ${ }^{1,2}$, Jelena Zagorska ${ }^{1}$, Indra Eihvalde ${ }^{1}$ \\ ${ }^{1}$ Latvia University of Life Sciences and Technologies, Latvia \\ 2Institute of Food Safety, Animal Health and Environment 'BIOR', Latvia \\ svetlana.baltrukova@gmail.com
}

\begin{abstract}
Bovine colostrum is a mammary gland secret which, due to its high immunoglobulin concentration, is necessary for the transfer of passive immunity to the calf, preventing diseases caused by microbial infections in the newborn ruminants. Colostrum, however, may contain pathogens and can be an infection transmitter, affecting morbidity and mortality rates of calves in the farms. Total plate count and immunoglobulin concentration are two main factors affecting colostrum quality, therefore the aim of the study was to analyse Latvian dairy herd colostrum quality.

Colostrum was collected from Holstein Black cows within the first six hours after calving, lactation period of animals ranged from $1^{\text {st }}$ to $4^{\text {th }}$ lactation. Colostrum samples $(\mathrm{n}=51,50 \mathrm{~mL})$ were collected from December 2018 to February 2019. Immunoglobulin concentration $(n=51)$ was defined by colostrometer (COLOSTROMETER ${ }^{\mathrm{tm}}$ Biogenics, USA), total solids content by optical refractometer (Model BX, UK). Staphylococcus spp. colony-forming unit (CFU) (LVS EN ISO 6888-1+A1:2007), the presence of Listeria spp. (LVS EN ISO 11290-1+A1:2007) and Salmonella spp. (LVS EN ISO 6579-1:2017) were examined in the colostrum samples $(n=20)$. Despite the high immunoglobulin concentration in the analysed samples, our research findings demonstrate suboptimal colostrum quality received by calves. That indicates the necessity for regular colostrum quality control and better management practise providing on the farm.
\end{abstract}

Key words: bovine colostrum, immunoglobulins, Staphylococcus spp., Listeria spp.

\section{Introduction}

Bovine colostrum is a mammary gland secret which, due to its high immunoglobulin (Ig) content, is necessary for the transfer of passive immunity to the calf, preventing diseases caused by microbial infections in the newborn ruminants. It is crucial for newborns to ensure adequate immunoglobulin concentration in the blood during the first 12 to 36 hours (HernándezCastellano et al., 2015). The highest concentration of biologically active compounds in colostrum is collected at the first milking after calving (Hurley \& Theil, 2011). According to Sacerdote et al. (2013), maximum Ig concentration in colostrum is in the first four hours after parturition, and six hours according to Borad \& Singh (2018) data. Latvian researchers' results (Eihvalde, Kairisa, \& Zagorska, 2012) confirmed that the lactation period influences immunoglobulin concentration, but the difference was not significant.

Contaminated colostrum, however, may contain pathogens and can be an infectious disease transmitter, affecting morbidity and mortality rates of animals in the farms (Stewart et al., 2005; Morales-delaNuez et al., 2011; Mohammed et al., 2018). Bovine milk contains complex microbiota that affects quality and safety of the product. Total plate count in raw milk from healthy bovine can range from $10^{3}$ to $10^{5} \mathrm{CFU}$ $\mathrm{mL}^{-1}$ (Porcellato et al., 2018).

Colostrum microbiological contamination can occur in different ways: milk can be contaminated with commensal bacteria from the teat skin, epithelial lining of teat canal, or via the lactiferous duct while it is being excreted; or due to the contamination of milk during production, collection, processing, handling, distribution and storage (Alegbeleye et al., 2018).
Staphylococcus spp., Streptococcus spp., Bacillus spp., Micrococcus spp., Corynebacterium spp. and sometimes coliforms, are common bovine commensal bacteria (Alegbeleye et al., 2018; Curone et al., 2018). Some pathogens such as Salmonella spp., Staphylococcus aureus, Listeria monocytogenes, Campylobacter jejuni, pathogenic Escherichia coli (Stewart et al., 2005; Elizondo-Salazar, Jayarao, \& Heinrichs, 2010) may be excreted into milk if they are localized in the mammary gland or associated lymph nodes due to systemic disease (Alegbeleye et $a l ., 2018)$. Total plate count and Ig concentration are two main factors affecting colostrum quality, therefore the aim of the study was to analyse Latvian dairy herd colostrum quality.

\section{Materials and Methods}

Colostrum was collected from Holstein Black cows within the first six hours after calving. Analysed animals lactation ranged from $1^{\text {st }}$ to $4^{\text {th }}$ (see Table 1 ). Before calving ( $>49$ days) 'Cepravin dry cow' (LTD MSD, Netherlands) was used. Active component of 'Cepravin dry cow' is cephalonium.

Colostrum samples $(\mathrm{n}=51,50 \mathrm{~mL})$ were collected at conventional farm ' $\mathrm{X}$ ', located in Zemgale, from December 2018 to February 2019. Colostrum samples were collected according to LVS EN ISO 707:2011 Milk and milk products - Guidance on sampling. Samples were used at $20{ }^{\circ} \mathrm{C}$ for detection of Ig and total solid content immediately after collection (Baltrukova, Zagorska, \& Eihvalde, 2019).

Samples for microbiological analysis immediately after collection were frozen $\left(-19 \pm 1{ }^{\circ} \mathrm{C}, 30 \mathrm{~min}\right)$ and delivered to the laboratory, stored for up to 30 days. 
The characteristics of analysed bovine colostrum samples

\begin{tabular}{|l|c|c|}
\hline \multicolumn{1}{|c|}{ Lactation period } & Number of samples & Period \\
\hline $1^{\text {st }}$ Lactation & 21 & $18.12 .2018-17.02 .2019$ \\
\hline $2^{\text {nd }}$ Lactation & 15 & $12.12 .2018-12.02 .2019$ \\
\hline $3^{\text {rd }}$ Lactation & 10 & $16.12 .2018-17.02 .2019$ \\
\hline $4^{\text {th }}$ Lactation & 5 & $23.12 .2018-10.02 .2019$ \\
\hline
\end{tabular}

The research was carried out at the Institute of Food Safety, Animal Health and Environment 'BIOR' at Food and Environmental Microbiology laboratory. Before microbiological tests, samples were removed from freezer, defrosted and homogenized in a water bath $\left(45 \pm 2{ }^{\circ} \mathrm{C}\right)$, after that samples preparation followed, according to: LVS EN ISO 6887-1:2017 'Microbiology of food and animal feeding stuffs Preparation of test samples, initial suspension and decimal dilutions for microbiological examination Part 1: General rules for the preparation of the initial suspension and decimal dilutions' and LVS EN ISO 6887-5:2011 'Microbiology of food and animal feeding stuffs - Preparation of test samples, initial suspension and decimal dilutions for microbiological examination - Part 5: Specific rules for the preparation of milk and milk products'.

Colostrometer (COLOSTROMETER ${ }^{\mathrm{tm}}$ Biogenics, USA) was used for Ig concentration determination, which is expressed as $\mathrm{mg} \mathrm{mL}^{-1}$. Percentage of total solids in colostrum $(\mathrm{n}=51)$ was measured using an optical refractometer (Model BX, UK) with a range of 0 to $34 \%$ Brix.

In colostrum samples $(\mathrm{n}=20)$ Staphylococcus spp. CFU mL $\mathrm{mL}^{-1}$ was examined according to LVS EN ISO 6888-1+A1:2007 Microbiology of food and animal feeding stuffs - Horizontal method for the enumeration of coagulase-positive staphylococci (Staphylococcus aureus and other species) - Part 1: Technique using Baird-Parker agar medium; medium used for microorganism isolation was B-P agar, MSA (Mannitol Salt Agar), TSA (Tryptic Soy Agar). Presence of Listeria spp. was examined according to 11290-1+A1:2007 Microbiology of the food chain Horizontal method for the detection and enumeration of Listeria monocytogenes and of Listeria spp. - Part 1: Detection method; medium used for microorganism isolation was Half-Frazer broth, Frazer broth, ALOA (Agar Listeria acc. to Ottaviani \& Agosti) agar, Blood agar. The presence of Salmonella spp. was detected according to LVS EN ISO 6579-1:2017 Microbiology of the food chain - Horizontal method for the detection, enumeration and serotyping of Salmonella - Part 1: Detection of Salmonella spp.; medium used for microorganism isolation was BPW (Buffered peptone water), RVS (Rappaport-Vassiliadis
Soy Peptone) broth, MKTTn (Muller-Kauffmann Tetrathionate-Novobiocin) broth, XLD (Xylose Lysine Deoxycholate) agar, Salmonella Chromogenic agar, Nutrient agar.

Isolated cultures (see Table 2) were identified using MALDI-TOF autoflex speed (Bruker, Germany) in Collection of Microorganism Culture of the Laboratory at the Institute of Food Safety, Animal Health and Environment 'BIOR'. For culture identifications Blood agar, Nutrient agar and TSA were used. All mediums in this study were purchased from 'Biolife' (Italy).

Descriptive statistics were used for data analysis, Duncan's test was calculated. The difference was considered statistically significant if $\mathrm{p}<0.05$.

\section{Results and Discussion}

Immunoglobulin concentration (mainly IgG and $\operatorname{IgM})$ is considered as one of the most important immune variables (Hernández-Castellano et al., 2015). Ig level in bovine colostrum varies considerably in different studies: $15-180 \mathrm{mg} \mathrm{mL}^{-1}$ (Borad \& Singh 2018), 1.4 - $204 \mathrm{mg} \mathrm{mL}^{-1}$ (Dunn et al., 2017), 1.8 $200.2 \mathrm{mg} \mathrm{mL}^{-1}$ (Morrill et al., 2012), 60 - $100 \mathrm{mg} \mathrm{mL}^{-1}$ (Sanchez et al., 2004). According to the findings by Lago et al. (2018), high-quality colostrum contains more than $50 \mathrm{mg} \mathrm{mL}^{-1}$ of $\mathrm{Ig}$, providing calves with passive immunity.

In the analysed colostrum samples, Ig concentrations varied from 39 to $150 \mathrm{mg} \mathrm{mL}^{-1}$ (Table 2). In the present study, mean Ig concentration (90.29 $\pm 3.33 \mathrm{mg} \mathrm{mL}^{-1}$ ) was similar to the results obtained by Yaylak, Yavuz, \& Özkaya (2017) - $91.00 \pm$ $4.48 \mathrm{mg} \mathrm{mL}^{-1}$ and it was higher than reported by Morrill et al. (2015) - $72.91 \pm 33.53 \mathrm{mg} \mathrm{mL}^{-1}$. Comparing immunoglobulin concentration among lactation period, a significant difference $(p<0.05)$ was established, the highest Ig concentration observed in colostrum obtained from cows after the $3^{\text {rd }}$ calving, all samples contained $\geq 89 \mathrm{mg} \mathrm{mL}^{-1} \mathrm{Ig}$ and $\geq 25 \%$ Brix. In the current study, the $1^{\text {st }}$ lactation cows had higher Ig level $\left(92.28 \pm 4.44 \mathrm{mg} \mathrm{mL}^{-1}\right)$ than the $2^{\text {nd }}$ lactation cows $\left(77.20 \pm 5.94 \mathrm{mg} \mathrm{mL}^{-1}\right)$, that corresponds to the results by Yaylak, Yavuz, \& Özkaya (2017) - $94.1 \pm 6.82 \mathrm{mg} \mathrm{mL}^{-1}$ and $88.03 \pm$ $5.66 \mathrm{mg} \mathrm{mL}^{-1}$, respectively. 
Table 2

Ig and total solids concentration in bovine colostrum

\begin{tabular}{|c|c|c|c|c|c|}
\hline Parameter & Quantity of samples, $\%$ & mean & SD & minimum & maximum \\
\hline \multicolumn{6}{|c|}{ Mean analysed bovine colostrum sample } \\
\hline $\operatorname{Ig}\left(\mathrm{mg} \mathrm{mL}^{-1}\right)$ & \multirow{2}{*}{100.0} & $90.29^{b}$ & 3.33 & 39 & 150 \\
\hline Brix (\%) & & $25.04^{\mathrm{B}}$ & 0.48 & 19 & 32 \\
\hline \multicolumn{6}{|c|}{$1^{\text {st }}$ Lactation } \\
\hline $\operatorname{Ig}\left(\mathrm{mg} \mathrm{mL}^{-1}\right)$ & \multirow{2}{*}{41.2} & $92.28^{\mathrm{b}}$ & 4.44 & 53 & 121 \\
\hline Brix (\%) & & $25.29^{\mathrm{B}}$ & 0.66 & 19 & 32 \\
\hline \multicolumn{6}{|c|}{$2^{\text {nd }}$ Lactation } \\
\hline $\operatorname{Ig}\left(\mathrm{mg} \mathrm{mL}^{-1}\right)$ & \multirow{2}{*}{29.4} & $77.20^{\mathrm{d}}$ & 5.94 & 40 & 118 \\
\hline Brix (\%) & & $22.80^{\mathrm{C}}$ & 0.73 & 20 & 30 \\
\hline \multicolumn{6}{|c|}{$3^{\text {rd }}$ Lactation } \\
\hline $\operatorname{Ig}\left(\mathrm{mg} \mathrm{mL}^{-1}\right)$ & \multirow{2}{*}{19.6} & $109.40^{\mathrm{a}}$ & 5.82 & 89 & 150 \\
\hline Brix (\%) & & $28.60^{\mathrm{A}}$ & 0.76 & 25 & 32 \\
\hline \multicolumn{6}{|c|}{$4^{\text {th }}$ Lactation } \\
\hline $\operatorname{Ig}\left(\mathrm{mg} \mathrm{mL}^{-1}\right)$ & \multirow{2}{*}{9.8} & $83.00^{\text {ac }}$ & 12.26 & 39 & 112 \\
\hline Brix $(\%)$ & & $23.6^{\mathrm{C}}$ & 0.93 & 21 & 26 \\
\hline
\end{tabular}

Duncan's test: different letters $(\mathrm{a}-\mathrm{d}, \mathrm{A}-\mathrm{C})$ in the column indicate significant difference among samples $(\mathrm{p}<0.05)$.

Total solids content in colostrum varied from 19 to $32 \%$. Mean concentration was $25.04 \pm 0.48 \%$, which is higher than reported by Lago et al. (2018) $20.3 \pm 2.9 \%$, by Morrill et al. (2015) $-21.24 \% \pm$ $4.43 \%$, by Quigley et al. (2013) - 23.8\% $\pm 3.5 \%$ and lower than the value reported by Yaylak, Yavuz, \& Özkaya (2017) - 26.61 $\pm 0.84 \%$.

Quigley et al. (2013) recommended 21\% Brix solids content to be considered as the breakpoint for high-quality bovine colostrum, which corresponds to Ig concentration of $\geq 50 \mathrm{mg} \mathrm{mL}^{-1}$ in colostrum. Morrill et al. (2015) specified Ig concentration of $\geq 50 \mathrm{mg}$ $\mathrm{mL}^{-1}$ in colostrum exactly for Holstein Black breed, analysed in the current research. Based on these recommendations, only in $3.9 \%$ colostrum samples Ig concentrations were lower than $50 \mathrm{mg} \mathrm{mL}^{-1}$, but other $96.1 \%$ samples contained more than $53 \mathrm{mg} \mathrm{mL}^{-1} \mathrm{Ig}$. In comparison, Lago et al. (2018) showed 80\% ( $\mathrm{n}=53)$ sample quality conformity, Morrill et al. (2012) reported $70.6 \%(\mathrm{n}=827)$ and Dunn et al. $(2017)-56 \%$ $(\mathrm{n}=1239)$.

Ig concentration was moderately positively correlated $(\mathrm{r}=0.76)$ with solids content $\%$ Brix (Figure 1). Morrill et al. (2015) reported similar results, e.g. $\mathrm{r}=0.79$, results by Yaylak, Yavuz, \& Özkaya (2017) reported $\mathrm{r}=0.70$.

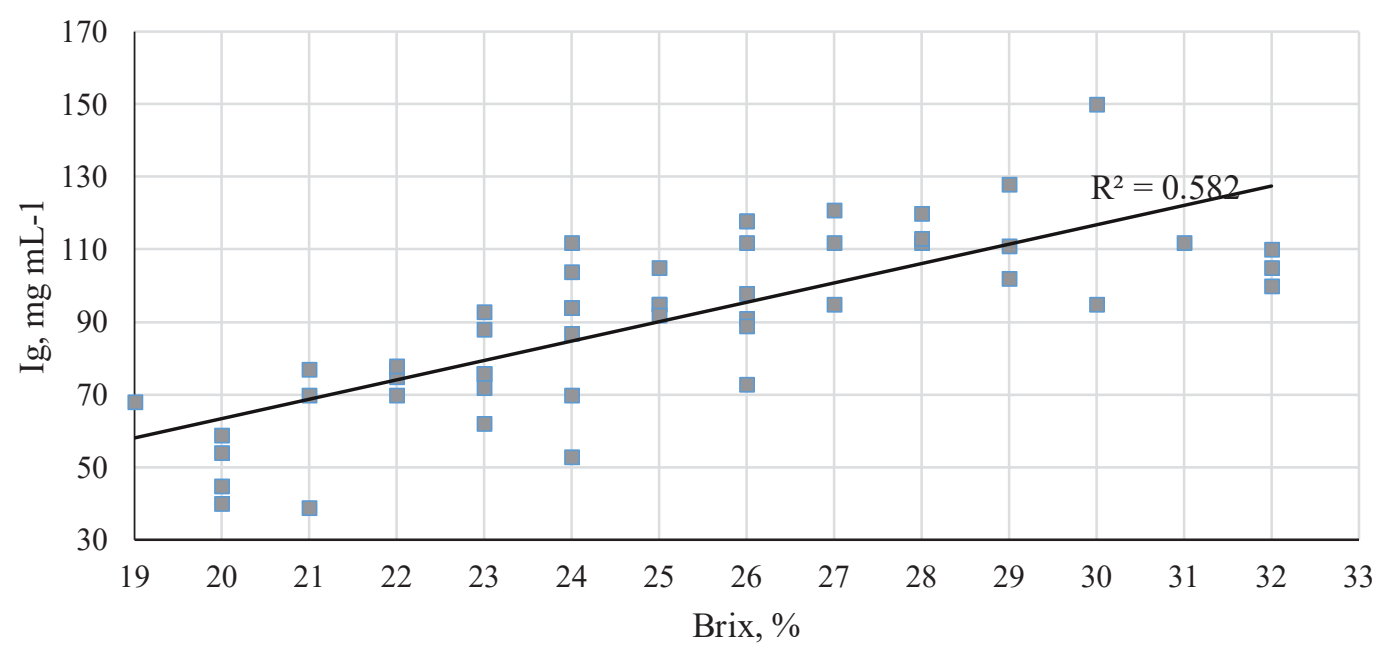

Figure 1. Correlation among solids content $\%$ Brix and Ig concentration in colostrum samples $(n=51)$. 
Bacteria species isolated from analysed bovine colostrum samples $(n=20)$

\begin{tabular}{|c|c|c|}
\hline Microorganisms & Species & Number of samples \\
\hline Listeria spp. & L. innocua & 5 \\
\hline \multirow{7}{*}{ Staphylococcus spp. } & S. aureus & 1 \\
\hline & S. epidermidis & 5 \\
\hline & S. haemolyticus & 4 \\
\hline & S. capitis & 3 \\
\hline & S. chromogenes & 4 \\
\hline & S. cohnii & 1 \\
\hline & S. xylosus & 1 \\
\hline \multirow{2}{*}{ Enterococcus spp. } & E. feacium & 4 \\
\hline & E. feacalis & 4 \\
\hline Bacillus spp. & B. clausii & 1 \\
\hline Macrococcus spp. & M. caseolyticus & 1 \\
\hline
\end{tabular}

Microbiological quality of colostrum is a very important factor, which can have a significant effect on calf health. Our previous study showed poor microbiological quality of obtained colostrum due to high total plate count $5.65 \log _{10} \mathrm{CFU} \mathrm{mL}^{-1}$ (Baltrukova, Zagorska, \& Eihvalde, 2019). Previous studies (Dunn et al., 2017) detected a wide range of pathogens in colostrum, therefore in the current study samples were examined for Listeria spp. (L.monocytogenes), Salmonella spp. presence and Staphylococcus spp. count (Table 2). They are considered the most common pathogens in bovine milk, that increase newborn calves mortality rate, as well as, it could be dangerous for humans if raw colostrum has been consumed without thermal treatment (Stewart et al., 2005; Alegbeleye et al., 2018; Mohammed et al., 2018).

In this study, Salmonella spp. and Listeria monocytogenes presence was not detected in any of the analysed colostrum samples. Listeria spp. was isolated from $25 \%$ of colostrum samples and identified as L. innocua; it is one of the non-pathogenic Listeria species, which is common in habitat and may contaminate farm environment, animal feed and water (Osman et al., 2014).

Two Enterococcus species were found on Blood agar and TSA: four colostrum samples contained E. feacium and the same number of samples contained E. faecalis; onBlood Agar Bacillus clausii and in TSA Macrococcus caseolyticus were detected.

Despite the 'Cepravin dry cow' use before calving, in the current study coagulase-negative Staphylococcus was the most common microorganism in bovine colostrum (Figure 2), which represents $100 \%$ of isolated microorganisms. Other studies showed similar results - Staphylococcus spp. were among the most frequent of the isolated bacteria in $57.7 \%$ (Fecteau et al., 2002) and $47.9 \%$
(Garedew et al., 2015) of cases. Coagulase-negative Staphylococcus species such as S. epidermidis, S. haemolyticus, S. capitis, S. chromogenes, S. cohnii, S. xylosus were identified in all analysed colostrum samples. The number of microorganisms varied from $10^{2}$ to $10^{4} \mathrm{CFU} \mathrm{mL} \mathrm{m}^{-1}$, and all samples contained more than one Staphylococcus specie. The number of microorganisms of the most frequently identified S. epidermidis and S. haemolyticus species varied from $10^{2}$ to $10^{3} \mathrm{CFU} \mathrm{mL}^{-1}$, but the least common $S$. cohnii varied from $10^{1}$ to $10^{2} \mathrm{CFU} \mathrm{mL}{ }^{-1}$, S. xylosus below $10^{1} \mathrm{CFU} \mathrm{mL}^{-1}$. S. epidermidis and S. haemolyticus are normal inhabitants of bovine skin and mucous membranes, but their strains show resistance to various antibiotics that may decrease curing effect of cow mastitis (Susan, Obansa, \& Anthony, 2014). $S$. epidermidis and $S$. aureus, isolated from milk samples in cows (Da Silva Chagas et al., 2017) and sheep (Vasil et al., 2017) with mastitis, have a role in biofilm production at different surfaces (milking and other equipment). Biofilms are a major form of microbial growth, they are considered to be responsible for the high resistance of microorganisms to sanitizers, allowing pathogenic and spoilage bacteria to survive the sanitization process (Flach et al., 2014).

S. chromogenes was detected in three samples

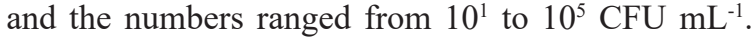
One colostrum sample contained $S$. aureus $4.0 \cdot 10^{2}$ $\mathrm{CFU} \mathrm{mL}^{-1}$ that did not exceed incremental norms $\left(<5.0 \cdot 10^{2} \mathrm{CFU} \mathrm{mL}^{-1}\right)$. S. aureus, S. chromogenes, E. feacalis, E. feacium are drug resistant (Susan, Obansa \& Anthonomy, 2014; Garedew et al., 2015) mastitis causative agents, which can be found in colostrum from diseased bovines (Alegbeleye et al., 2018).

Summarizing study results can be concluded that some measures should be applied for improving colostrum quality, as a significant part of identified 


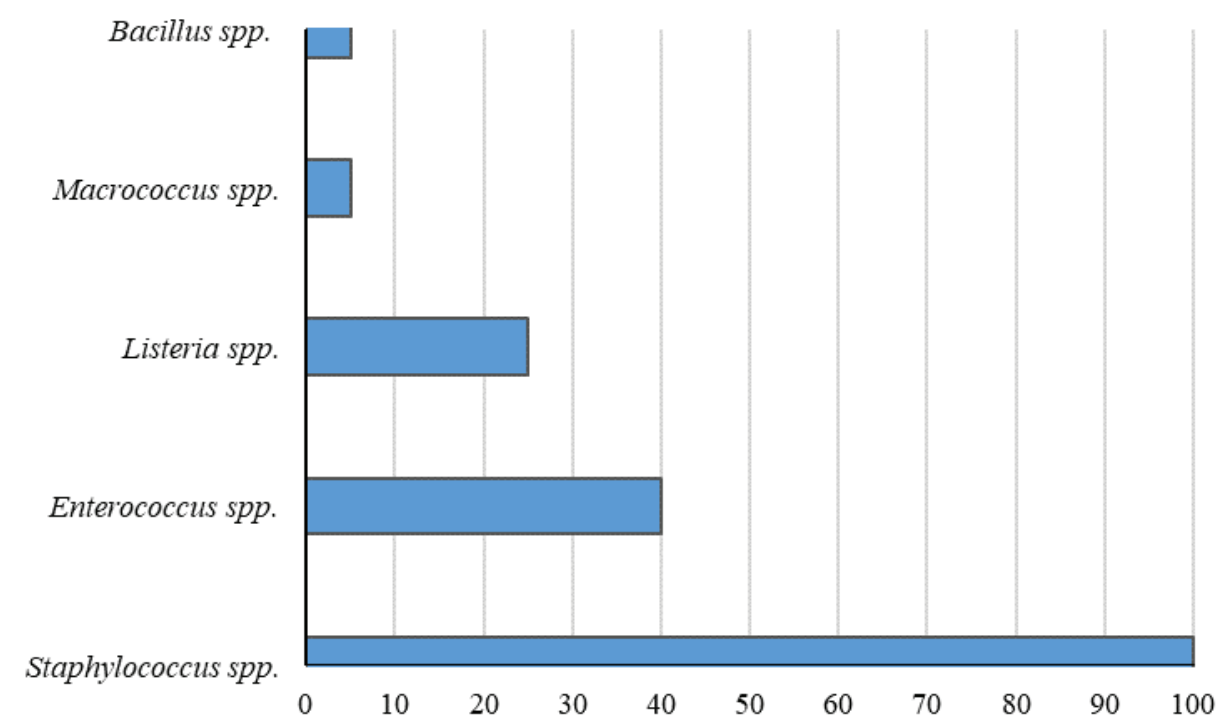

Figure 2. Distribution of isolated microorganism genus in bovine colostrum samples (\%).

microorganisms are pathogenic, antibiotic resistant, and biofilm producing species (Susan, Obansa, \& Anthonomy, 2014; Da Silva Chagas et al., 2017; Vasil et al., 2017). Enhanced animal health and hygienic conditions on dairy farms can minimize colostrum bacterial contamination (Alegbeleye et al., 2018). One more possible solution for minimizing bacterial contamination of colostrum and decreasing calf mortality rate is heat treatment. The results of a study by Elizondo-Salazar, Jayarao, \& Heinrichs (2010) indicate that heat treatment of bovine colostrum at 60 ${ }^{\circ} \mathrm{C}$ for 30 to $60 \mathrm{~min}$ may be used as an optimal regime to observe a less denaturation in $\mathrm{IgG}$ concentration and a significant decrease in plate count in samples (Elizondo-Salazar, Jayarao, \& Heinrichs, 2010). That confirms the study by Malmuthuge et al. (2015) which showed that heat treatment of colostrum could serve as an effective method for reducing pathogen exposure to newborn calves. Further researches are needed to obtain high quality colostrum andexplaining interaction among immunoglobulins (class, concentration) and specific pathogens. Thermal treatment importance for colostrum quality should be evaluated as well.

\section{Conclusions}

According to Ig concentration and total solids content, analysed colostrum samples belong to highquality colostrum group.

In the current study improper microbiological quality of analysed colostrum was highlighted, still Staphylococcus genus was the most frequently identified in the analysed samples. Pathogen Staphylococcus specie - S. aureus was determined in one colostrum sample. L. innocua was identified in $25 \%$ of analysed colostrum samples. Salmonella spp. and L. monocytogenes were not detected.

Despite high immunoglobulin concentration in the analysed samples, our research findings demonstrate suboptimal colostrum quality received by calves. That indicates the necessity for regular colostrum quality control and better management practise providing on the farm.

\section{Acknowledgements}

The research was supported by Institute of Food Safety, Animal Health and Environment 'BIOR'.

I am grateful to Laura Alksne for help in the studied microorganism culture identification with MALDI-TOF.

\section{References}

1. Alegbeleye, O.O., Guimarães, J.T., Cruz, A.G., \& Sant'Ana, A.S. (2018). Hazards of a 'Healthy' Trend? An Appraisal of the Risks of Raw Milk Consumption and the Potential of Novel Treatment Technologies to Serve as Alternatives to Pasteurization. Trends Food Sci Technol. 82(July), 148-166. DOI: 10.1016/j. tifs.2018.10.007.

2. Baltrukova, S., Zagorska, J., \& Eihvalde, I. (2019). Evaluation of Microbiological Quality of Colostrum FoodBalt 2019. 13th Baltic Conference on Food Science 'Food. Nutrition. Well-Being'. 2-3 May, Jelgava, LLU, 2019, 45-49. DOI: 10.22616/FoodBalt.2019.017.

3. Borad, S.G., \& Singh, A.K. (2018). Colostrum Immunoglobulins: Processing, Preservation and Application Aspects. Int Dairy J. 85, 201-210. DOI: 10.1016/j.idairyj.2018.05.016. 
4. Curone, G., Filipe, J., Cremonesi, P., Trevisi, E., Amadori, M., Pollera, C., ... Riva, F. (2018). What We Have Lost: Mastitis Resistance in Holstein Friesians and in a Local Cattle Breed. Res Vet Sci. 116 (February), 88-98. DOI: 10.1016/j.rvsc.2017.11.020.

5. Da Silva Chagas, L.G., Melo, P.D., Brasao, S.C., Silvestre, G.B., Guimaraes, E.C., \& Lima, A.M. (2017). Evaluation of Biofilm Formation by Bacterial Strains Isolated from Milking Equipment and Milk Samples from Cows with Mastitis. Semin: Cienc Agrar. 38(4), 1887-1895. DOI: 10.5433/1679-0359.2017v38n $4 \mathrm{p} 1887$.

6. Dunn, A., Ashfield, A., Earley, B., Welsh, M., Gordon, A., \& Morrison, S.J. (2017). Evaluation of Factors Associated with Immunoglobulin G, Fat, Protein, and Lactose Concentrations in Bovine Colostrum and Colostrum Management Practices in Grassland-Based Dairy Systems in Northern Ireland. J Dairy Sci. 100(3), 2068-2079. DOI: 10.3168/jds.2016-11724.

7. Eihvalde, I., Kairiša D., \& Zagorska, J. (2012). Analysis of Factors Influencing Immunoglobulin Concentration in Colostrum of Dairy Cows. Scientific Papers Animal Science Series. 57(94), 256-259.

8. Elizondo-Salazar, J.A., Jayarao, B.M., \& Heinrichs, A.J. (2010). Effect of Heat Treatment of Bovine Colostrum on Bacterial Counts, Viscosity, and Immunoglobulin G Concentration. J Dairy Sci. 93(3), 961967. DOI: 10.3168/jds.2009-2388.

9. Fecteau, G., Baillargeon, P., Higgins, M.R., \& Fortin, P.J. (2002). Bacterial Contamination of Colostrum Fed to Newborn Calves in Quebec Dairy Herds. Canadian Vet J. 43(7), 523-527.

10. Flach, J., Grzybowski, V., Toniazzo, G., \& Corção, G. (2014). Adhesion and Production of Degrading Enzymes by Bacteria Isolated from Biofilms in Raw Milk Cooling Tanks. Food Sci Technol. 34(3), 571576. DOI: 10.1590/1678-457x.6374.

11. Garedew, L., Mengesha, D., Birhanu, A., \& Mohammed, A. (2015). Diverse Gram-Positive Bacteria Identified from Raw and Pasteurized Cow Milk Consumed at Gondar Town and Its Environs, Ethiopia. Ethiopian Vet J. 19(1), 49-61. DOI: 10.4314/evj.v19i1.3.

12. Hernández-Castellano, L.E., Morales-delaNuez, A., Sánchez-Macías, D., Moreno-Indias, I., Torres, A., Capote, J., ... Castro, N. (2015). The Effect of Colostrum Source (Goat vs. Sheep) and Timing of the First Colostrum Feeding (2h vs. 14h after Birth) on Body Weight and Immune Status of Artificially Reared Newborn Lambs. J Dairy Sci. 98(1), 204-210. DOI: 10.3168/jds.2014-8350.

13. Hurley, W.L., \& Theil, P.K. (2011). Perspectives on Immunoglobulins in Colostrum and Milk. Nutrients. 3(4), 442-474. DOI: 10.3390/nu3040442.

14. Lago, A., Socha, M., Geiger, A., Cook, D., Silva-del-Río, N., Blanc, C., ... Leonardi, C. (2018). Efficacy of Colostrum Replacer versus Maternal Colostrum on Immunological Status, Health, and Growth of Preweaned Dairy Calves. J Dairy Sci. 101(2), 1344-1354. DOI: 10.3168/jds.2017-13032.

15. Malmuthuge, N., Chen, Y., Liang, G., Goonewardene, L.A., \& Guan, L.L. (2015). Heat-Treated Colostrum Feeding Promotes Beneficial Bacteria Colonization in the Small Intestine of Neonatal Calves. J Dairy Sci. 98(11), 8044-8053. DOI: 10.3168/jds.2015-9607.

16. Mohammed, S.A., Marouf, S.A., Erfana, A.M., El-Haleem El-Jakee, J.K., Hessain, A.M., Dawoud, T.M., ... Moussa, I.M. (2018). Risk Factors Associated with E. coli Causing Neonatal Calf Diarrhoea. Saudi J Biol Sci. Article in press. DOI: 10.1016/j.sjbs.2018.07.008.

17. Morales-delaNuez, A., Moreno-Indias, I., Sánchez-Macías, D., Capote, J., Juste, M., Castro N., ... Argüello A. (2011). Sodium Dodecyl Sulfate Reduces Bacterial Contamination in Goat Colostrum without Negative Effects on Immune Passive Transfer in Goat Kids. J Dairy Sci. 94(1), 410-415. DOI: 10.3168/jds.20103624.

18. Morrill, K.M., Robertson, K.E., Spring, H.D., Robinson, M.M., \& Tyler, A.L. (2015). Validating a Refractometer to Evaluate Immunoglobulin G Concentration in Jersey Colostrum and the Effect of Multiple Freeze-thaw Cycles on Evaluating Colostrum Quality. J Dairy Sci. 98(1), 595-601. DOI: 10.3168/jds.2014-8730.

19. Morrill, K.M., Conrad, E., Lago, A., Campbell, J., Quigley, J., \& Tyler, H. (2012). Nationwide Evaluation of Quality and Composition of Colostrum on Dairy Farms in the United States. J Dairy Sci. 95(7), 39974005. DOI: 10.3168/jds.2011-5174.

20. Osman, K.M., Samir, A.O., Ahmed, Z., \& Tara, R. (2014). Confirmed Low Prevalence of Listeria Mastitis in She-Camel Milk Delivers a Safe, Alternative Milk for Human Consumption. Acta Trop. 130(1), 1-6. DOI: $10.1016 /$ j.actatropica.2013.10.001.

21. Porcellato, D., Aspholm, M. Skeie, S.B., Monshaugen, M. Brendehaug, J., \& Mellegård, H. (2018). Microbial Diversity of Consumption Milk during Processing and Storage. Int J Food Microbiol. 266, 21-30. DOI: 10.1016/j.ijfoodmicro.2017.11.004. 
22. Quigley, J.D., Lago, A., Chapman, C., Erickson, P., \& Polo, J. (2013). Evaluation of the Brix Refractometer to Estimate Immunoglobulin G Concentration in Bovine Colostrum. J Dairy Sci. 96(2), 1148-1155. DOI: 10.3168/jds.2012-5823.

23. Sacerdote, P., Mussano, F., Franchi, A.E., Panerai, S., Bussolati, B., Carossa, G., ... Bussolati, S. (2013). Biological Components in a Standardized Derivative of Bovine Colostrum. J Dairy Sci. 96(3), 1745-1754. DOI: $10.3168 /$ jds.2012-5928.

24. Sanchez, J., Markham, F., Dohoo, I., Sheppard, J., Keefe, K., \& Leslie, G. (2004). Milk Antibodies against Ostertagia Ostertagi: Relationships with Milk IgG and Production Parameters in Lactating Dairy Cattle. Vet Parasitol. 120(4), 319-330. DOI: 10.1016/j.vetpar.2004.01.010.

25. Stewart, S., Godden, S., Bey, R., Rapnicki, P., Fetrow, S., Farnsworth, R., ... Ferrouillet, C. (2005). Preventing Bacterial Contamination and Proliferation During the Harvest, Storage, and Feeding of Fresh Bovine Colostrum. J Dairy Sci. 88(7), 2571-2578. DOI: 10.3168/jds.S0022-0302(05)72933-7.

26. Susan, O., Obansa, A., \& Anthony, M. (2014). Microbiological Quality of Dairy Cattle Products. $B r$ Microbiol Res J. 4(12), 1409-1417. DOI: 10.9734/bmrj/2014/11112.

27. Vasil, M., Farkašova, Z., Elečko, J, Illek, J., \& Zigo, F. (2017). Comparison of biofilm formation by Staphylococcus aureus and Staphylococcus epidermidis strains isolated from sheep milk using three diagnostic methods. Pol J Vet Sci. 20(4), 795-801. DOI: 10.1515 / pjvs-2017-0100.

28. Yaylak, E., Yavuz, M., \& Özkaya, S. (2017). The Effects of Calving Season and Parity on Colostrum Quality of Holstein Cows. Indian J Anim Res. 51(3), 594-598. DOI: 10.18805/ijar.11470. 